\title{
In the thick of it: cerebral venous sinus thrombosis precipitated by iron-deficiency anaemia and sickle cell trait
}

\author{
Ian S Boon, ${ }^{1}$ Kerry Jo Starkey, ${ }^{1,2}$ Oksana Samsonova, ${ }^{3}$ \\ Andrew McDonald Johnston ${ }^{4,5,6}$
}

${ }^{1}$ Department of Clinical Decision Unit, University Hospitals Birmingham NHS Foundation Trust, Birmingham, UK

${ }^{2}$ Army Medical Directorate, Surrey, UK

${ }^{3}$ Department of Elderly Care, University Hospitals

Birmingham NHS Foundation Trust, Birmingham, UK

${ }^{4}$ Department of Anaesthesia and Intensive Care Medicine, Queen Elizabeth Hospital Birmingham, Birmingham, Birmingham, UK

${ }^{5}$ Department of Military Anaesthesia and Critical Care, Royal Centre for Defence Medicine, Birmingham, Birmingham, UK ${ }^{6}$ Department of Military Medicine, Royal Centre for Defence Medicine,

Birmingham, Birmingham, UK

Correspondence to

Dr lan S Boon,

ianboon@doctors.org.uk

Accepted 1 May 2016

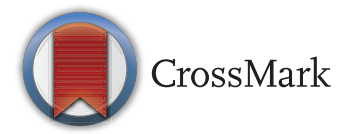

To cite: Boon IS, Starkey KJ, Samsonova 0, et al. BMJ Case Rep Published online: [please include Day Month Year] doi:10.1136/bcr-2016215399

\section{DESCRIPTION}

An 18-year-old man of West-African origin presented with 3 days of severe headache, photophobia, nausea and vomiting. He had lived in the UK for 5 years. There was no family history of clotting disorder. A year ago, his doctor treated him with albendazole for threadworms. He did not take any regular medications. Examination revealed no neurological abnormality, meningism or hepatosplenomegaly. Fundoscopy showed no papilloedema.

Blood tests detected microcytic anaemia with haemoglobin of $74 \mathrm{~g} / \mathrm{L}$ (normal range 135-180 g/ L). Iron studies confirmed iron deficiency. Electrophoresis detected haemoglobin S confirming sickle cell trait. Antiphospholipid, anticardiolipin, haemolysis, retroviral and autoimmune screens were negative. Incidentally, he was Factor VII deficient. Clotting studies were normal, and the International Normalised Ratio (INR) was 1.4. No ova, parasites or cysts were present on stool microscopy.

CT scan of the head revealed an area of high density (figure 1) which was confirmed to be a cerebral venous sinus thrombosis (CVST) on CT venogram (figure 2 ).

Low-molecular-weight heparin and iron were administered on the advice of a haematologist. The Factor VII deficiency was either a transient response to CVST or an inherited heterozygous Factor VII

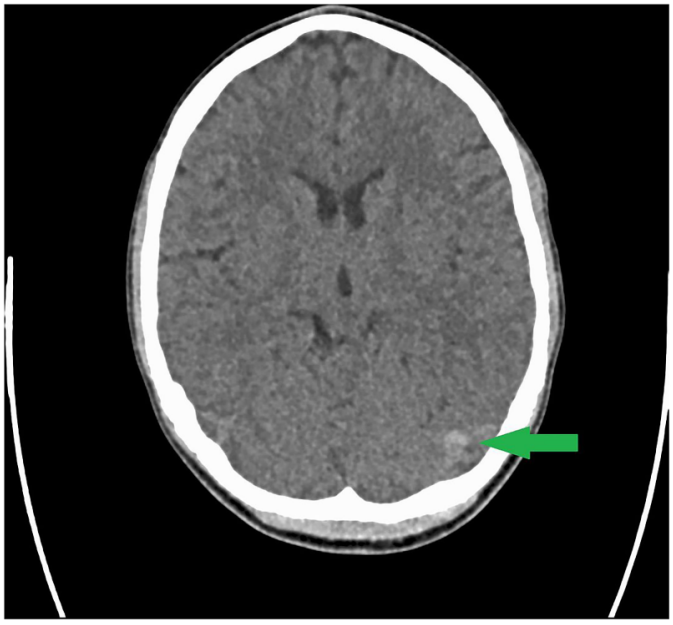

Figure 1 CT of the head without contrast shows an area of high density (arrow) raising the possibility of thrombus within the left transverse sinus. deficiency where baseline INR is higher. Warfarin was prescribed with an INR target of 3.0 to avoid under-anticoagulation. The patient's headache resolved and he was discharged with plans for follow-up by a haematologist.

CVST is a form of venous thrombosis within the intracranial venous sinuses. ${ }^{1}$ The incidence is $3-4$ cases per million individuals with an $8 \%$ mortality rate. $^{2}$ CVST is predisposed to by prothrombotic disorders, anaemia and is associated with a number of clinical conditions. ${ }^{1}{ }^{2}$ Sickle cell disease contributes to a hypercoagulable state by distortion of the phospholipid membrane of red blood cells and inappropriate activation of tissue factors on endothelial cells. ${ }^{3}$

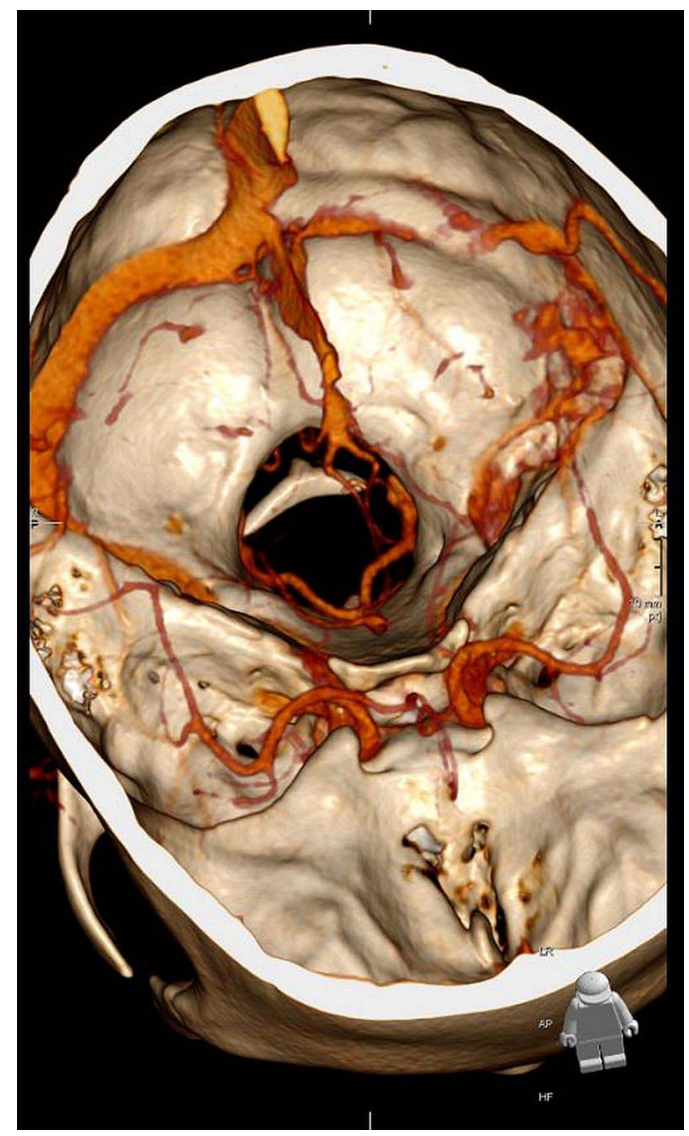

Figure 2 Three-dimensional reconstruction of CT head venogram revealed cerebral venous sinus thrombosis within the left transverse sinus, sigmoid sinus and jugular bulb. A further non-occlusive thrombus was seen within the right jugular bulb. 


\section{Learning points}

- Cerebral venous sinus thrombosis (CVST) is a rare entity which usually presents subacutely over several days or weeks. ${ }^{12}$ Patients present with wide-ranging symptoms, commonly headache, neurologic deficit, altered consciousness and seizures reflecting the underlying brain damage and raised intracranial pressure due to venous thrombosis. ${ }^{12}$

- CVST may be provoked by prothrombotic factors associated with anaemia and a myriad of other clinical conditions, including sickle cell disease, protein $C$ and protein $S$ deficiency, anticardiolipin antibodies, systemic lupus erythematous, dehydration, infection, sepsis and malignancy. ${ }^{12}$ These medical conditions should be investigated and excluded.

- Treatment of CVST requires haematological advice and follow-up. Anticoagulation is recommended to prevent thrombus extending and allow fibrinolysis of thrombus and recanalisation of the affected veins. Patients with CVST complicated by intracranial haemorrhage should be anticoagulated cautiously. Low-molecular-weight heparin should be followed by treatment with warfarin. ${ }^{12}$ Direct oral anticoagulants are not yet licensed for treatment of CVST.
Contributors ISB obtained consent of the patient, collected data, reviewed the literature and wrote the manuscript. KJS collected data and drafted the manuscript. OS reviewed the manuscript. AMJ identified the patient, revised the manuscript and supervised the write up.

Competing interests None declared.

Patient consent Obtained.

Provenance and peer review Not commissioned; externally peer reviewed.

\section{REFERENCES}

1 Hashmi M, Wasay M. Caring for cerebral venous sinus thrombosis in children. J Emerg Trauma Shock 2011;4:389-94.

2 Chiewvit P, Piyapittayanan S, Poungvarin N. Cerebral venous thrombosis: diagnosis dilemma. Neurol Int 2011;3:e13.

3 Rahimi Z, Parsian A. Sickle cell disease and venous thromboembolism. Mediterr J Hematol Infect Dis 2011;3:e2011024.

Copyright 2016 BMJ Publishing Group. All rights reserved. For permission to reuse any of this content visit http://group.bmj.com/group/rights-licensing/permissions.

BMJ Case Report Fellows may re-use this article for personal use and teaching without any further permission.

Become a Fellow of BMJ Case Reports today and you can:

- Submit as many cases as you like

- Enjoy fast sympathetic peer review and rapid publication of accepted articles

- Access all the published articles

- Re-use any of the published material for personal use and teaching without further permission

For information on Institutional Fellowships contact consortiasales@bmjgroup.com

Visit casereports.bmj.com for more articles like this and to become a Fellow 